\title{
AWATER PRICING STRATEGIES AS AN ECONOMIC TOOL TOWARDS WATER SECURITY
}

Nadim, I. E. ${ }^{(1)}$; Saad, S. A. ${ }^{(2)}$ and Helal, Ngwa, S. ${ }^{(3)}$

1) Faculty of Commerce, Ain Shams University 2) Strateic Research Unit (SRU), National Water Research Center, Ministry of Water Resources and Irrigation, Egypt 3) Egyptian Public Authority for Drainage Projects

\begin{abstract}
Scarcity, value in use, and easiness of access; among others; determine the economic value of goods as well as the willingness to pay for these goods. Although, water is not an exemption, it is a life sustaining good for all living creatures and an input for almost all products. Thus, the application of economic tools in dealing with the provision of water should be controlled by consideration the very special nature of water.

On one hand, water pricing presents one of the economic tools to promote the efficient use of water, and to supply necessary funds to develop water infrastructure. Nonetheless, if they are not wisely formulated, they may jeopardise the society's socio-economic-political wellbeing.

On the other hand, inherited social and economic rights over decades allowing people to get water for low unrealistic charges or even for free represents a main obstacle confronting the implementation of any pricing strategy.

Following the analytical descriptive method, secondary data associated with the applied pricing methods were obtained from published reports to allow the assessment and analysis of such data to realize the most applicable water pricing strategy.

Nonetheless, and due to lack of a standardized methodology to price water in different usages internationally. Water pricing should be based on a policy coherence that mainly takes into consideration the socio-economic security goals of the society and considers the interaction, prioritization and overlap between these goals in order to minimize trade-offs.
\end{abstract}

Key Words: Water pricing, water value, water cost, water markets, conservation, strategy, water security, reliability. 
J. Environ. Sci.

Institute of Environmental Studies and Research - Ain Shams University

\section{INTRODUCTION}

Water is not only a vital element for life but it's also an indispensable factor of production and economic growth (WB, 2016). With the increasingly widening water gap between supply and demand; life and economic growth are at risk. Nonetheless, different challenges led to widening the gap world widely; of which water misuse, pollution, climate change negative impacts, population unplanned growth, and enhanced living standards. While Egypt is not an exception, it faces an additional challenge due to calls for the redistribution of the Nile water by the Nile Basin countries' threatening Egypt's historical share (55.5 Billion cubic meter according to the 1959 agreement with Sudan), which presents almost the sole source of Egypt's fresh water. Moreover, the construction of the Renaissance Dam over the Blue Nile in Ethiopia- where $80 \%$ of Egypt's fresh water originatesexacerbates the challenge facing the country.

Thus, the country is highly encouraged to maintain a comprehensive strategy towards maximizing the socio-economic-political security of the society through the wise use of water to accomplish equity, efficiency, and sustainability. Improving water management is a multi-facet-continued task that targets water saving through the expansion of water delivery network, the rehabilitation of aging water distribution networks, pollution control, wastewater treatment for reuse, the application of water saving technologies and strategies, etc.

Nonetheless, achieving these vital goals requires the allocation of big investments in the sector. While on the other hand, the economy is facing 
serious slow-down after two revolutions in a short time span that have negatively impacted the country's financial resources either from the tourism sector, Egyptians' foreign transfers, exportation, etc. This gap between available finance and requirements accelerated the need for the application of a comprehensive water pricing strategy which would be effectively implemented as a water saving tool without jeopardizing the stability of the society.

\section{PROBLEM IDENTIFICATION}

Egypt is facing a multifaceted water shortage problem, where its water resources cannot meet the increasingly demands. Yet the economic management of this finite source is subject to great debate among water economists. Where on one hand, a group claims that water is an economic good subject to the supply and demand theory and the free markets' rules, implying that who cannot afford the assigned prices/costs should not get water, neglecting the special nature of water as an essential element for live. Yet, on the other hand, the international society did not fully agree with the concept and called for considering water's indirect functions as a public good. Being one of the basic human rights, which fulfills vital social goals and basic needs, water is not supposed to be priced according to commercial criteria.

Egypt cannot endorse neither of the two concepts; as for the first concept; water as economic good; it neglects the negative socio-economic impacts on the poor and near poor who represent around 40 percent of the population. While providing water without applying suitable cost recovery mechanisms presents an inapplicable claim. As according to the estimation of the United 
Nations Development Program in 2002; the required investments to achieve $100 \%$ coverage on municipal water and wastewater services only is about US $\$ 19.2$ billion (of which US\$4 billion is needed to maintain the current levels of service) (El-Saharty Sameh et al., 2005), which would place a huge burden over the public budget.

Furthermore, the damage costs of poor water quality affecting human health and land productivity according to the United Nations Development Program together with the National Planning Institute of Egypt (2005) reached about LE 5.35 billion or 1.8\% of GDP in 2003, reflecting one of the negative impacts resulting from the continuation of business as usual (BAU) or taking no action. Furthermore, the economy is highly affected with the drawbacks resulting from the weak inclusion of an important driving factor such as water; either when setting priorities or on drawing the main line of the nation's strategy (Flournoy \& Brimley, 2006).

Therefore, and in order to meet the ends, guiding principles to decision makers are presented to guide selecting the suitable pricing method.

\section{STUDY OBJECTIVE}

The researchers intend to present guiding principles to decision makers towards reaching the most applicable pricing method. The study does not intent to provide a monetized value to water due to the variation in nature and range of water-related pricing systems; lacking of sufficient data and unavailability of standardized valuation methods. 


\section{RESEARCH QUESTIONS}

The research poses the following questions:

- What are the factors determining water value?

- What are the driving forces towards water management strategy?

- What are the items presenting the full cost of water?

- Is irrigation water pricing rational from the society's point of view?

- How would applying water for recreational uses during water shortage periods impacts the societal satisfaction?

\section{METHODOLOGY}

Following the analytical descriptive method, secondary data associated with water pricing methods were obtained from published studies on the international libraries on the Internet reached through the Egyptian Knowledge Bank, in addition to the resources in the Central Library-Ein Shams University and published reports by public authorizes in a number of countries of middle income to allow the documentation and analysis of the applied methods; pricing to save water, pricing to return costs including the sub-methods of returing running costs, full economic cost, or the full cost; to realize the guiding principles towards the most applicable water pricing strategy from increasing-block rates (IBR), variable unit price (VUP) or uniform volumetric pricing to achieve water security either through encouraging water conservation or by collecting the cost of delivering water. 
J. Environ. Sci.

Institute of Environmental Studies and Research - Ain Shams University

\section{REVIEW OF LITERATURE}

\section{- The Right to Water: from concept to implementation:}

By Céline Dubreuil, 2006, ISBN: 92-95017-11-0, the World Water Council, France.

The report stresses the fact that the recognition of the right to water and sanitation in the international law; through the General Comment $\mathrm{N}^{\circ} 15$ of the International Covenant on Economic, Social and Cultural Rights; and increasingly in national law will not automatically lead to implementation. As millions of people are still deprived of this live-sustaining right owing to the lack of clear definition of rights, obligations and responsibilities of each stakeholder. In the meantime, the report confirms that although the explicit mention of the right to water in national laws is of high importance, the lack of it should not be an excuse not to implement this right.

To guarantee the implementation of this right, the report spots the importance of both the identification of an authority; on the national level; to oversee the sustainable implementation of this right for present and future generations giving special attention to extending the service to the yet unserved population, as well as the allocation of the associated human and financial resources.

Emphasizing the importance of solidarity between citizens and even nations and that solidarity should be institutionalized to facilitate the enjoyment of the right to water and sanitation to all especially the poorest and marginalized people. 
To put the right to water and sanitation into implementation, the report confirms the important role of international organizations with their specialized agencies, trade and financial institutions in respecting this right in their policies and operations and in formulating and implementing international agreements.

In conclusion, the report stresses that enabling all people to sustainable access to safe water and sanitation requires the collaboration of all parties towards putting the right into implementation.

\section{- Water as an Economic Good: An Approach to the Egyptian Economy:}

By Mervat Doss and Grant Milne, the Beijer Workshop on "Property Rights Structures and Environmental Resource Management” Egypt, March, 2001.

The study draws connections between the current situation by providing water as a free resource and a human right on one hand with the improper allocation of water, mismanagement of the resource and inefficient practices on the other hand. Recommending treating water as a valuable economic good as the way-out from the growing scarcity of freshwater resources in Egypt either due to limited resources, growing demand, water pollution, mismanagement of the resource, etc. As economic tools will improve water allocation between different water users, usages, and locations, while economic incentives' essential role in minimizing water pollution.

Available water resources for use are limited to $55.5 \mathrm{BCM} / \mathrm{yr}$ presenting Egypt's share in the River Nile, in addition to $1.0 \mathrm{BCM} / \mathrm{yr}$ of effective rainfall on the northern coast of the Delta, non-renewable groundwater for western desert and Sinai. While water requirements for different sectors is 75 
$\mathrm{BCM} / \mathrm{yr}$. The gap between the two figures; about $20 \mathrm{BCM} / \mathrm{yr}$; is being overcome by recycling, where the overall efficiency of the Nile system in Egypt is about $75 \%$.

Although the annual population growth rate has steadily declined from $2.4 \%$ during the 1976-1986 decade, to $1.9 \%$ for the 1996-2006 period. Population growth will continue and is expected to range from 120 to 150 million by 2050 . Water requirements are expected to increase by $20 \%$ (15 $\mathrm{BCM} / \mathrm{yr}$ ) by the year 2020. Additionally, water quality deterioration is expected to increase the severity of the water scarcity problem or add to the cost of treatment. Population predictions is forecasted to bring Egypt down to $500 \mathrm{~m} 3 / \mathrm{ca} / \mathrm{yr}$ or the absolute water scarcity by the year 2025 .

Negative climate change impacts affecting the River Nile are being expected to affect Egypt not only within its borders, but also within the whole basin. Where on the one hand, Egypt dependency on the Nile River as almost a sole source of its limited fresh water resource. This resource is identified as one of the three most vulnerable sectors to climate change in Egypt according to a climate change prediction model. Where, the other two sectors are coastal zones and agricultural resources.

On the other hand, being the most downstream county on the Nile, and where the Nile River proven sensitive to temperature and precipitation changes mainly caused by its low runoff/rainfall ratio (4\%) combined with Egypt's vulnerability to changes in river flows; shown by the prolonged 1979 1987 drought which forced Egypt to reduce its water use despite the interannual storage in Lake Nasser behind the High Aswan Dam on the other 
hand; puts Egypt at stake.

Nonetheless, imports of cereals, oils and sugar puts Egypt as one of the largest food importers in the world exhausting the country's foreign exchange resources. The total imports bill reached 5000 million US\$ in 2009, where cereals contributed with $49 \%$ of the import bill; approximately $32.6 \%$ of the total accounted for wheat alone.

\section{RESULTS}

- The value of water should reflect the societal goals of the society while maintaining the human right in water through delivering a set quantity as a basic human right for free, reducing poverty and enhancing livelihood, and to apply the pricing strategy that guide the society towards accomplishing its goals.

- All aspects of water should be taken into consideration on determining the water management strategy to be enforced due to the special nature of water.

- The full cost of water should include the opportunity cost of water as well as the environmental externalities to present a context for setting water prices, effluent charges, incentives for rationalizing water use and control pollution.

- The residential price elasticity may increase when price information is posted on water bills.

- Pricing irrigation water for those with very small holdings may affect the inter-sectoral equity by increasing the hardship of life in rural areas compared to urban residents even if farmers turn to the use of groundwater 
when possible. As increasing the paid cost for getting water (either through applying water pricing or increasing the prices of water pumps or diesel charges) would have a direct and tangible impact over the social welfare of the farmers.

- The expansion in providing fresh water for recreational uses; e.g. water ways and pools in resorts and luxurious compounds should be put under further socio-economic study especially on the increasing threats of an upcoming water scarcity crisis upon the completion of the Renaissance Dam and any other dams to be constructed in any of the Nile basin countries'.

\section{DISCUSSION}

The combined effects of population growth, climate change, rising living standards and growing urbanization on one hand, while on the other hand, the supply of water is increasingly becoming uncertain and limited, led to an increasingly water gap. This critical situation necessitates the strict as well as wise application of all possible tools to save and redistribute water to accomplish and sustain water security in Egypt.

According to the United Nations Development Program (UNDP, 2006) water security is:

"About ensuring that every person has reliable access to enough safe water at an affordable price to lead a healthy, dignified and productive life, while maintaining the ecological systems that provide water and also depend on water." 
Internationally, water pricing is considered as an important tool to save water especially following the declaration of the Agenda 21 and the Dublin Principles; which stated that water is an economic good with an economic value in all its competing uses (Rogers et al., 1998). Nonetheless, this principle should not be interpreted as a deprivation of using water unless affording its cost. As water defers from other goods for being a vital source for life, which called the United Nations to officially declare water as a human right in 2002 through the General Comment no. 15, of the International Covenant on Economic, Social and cultural Rights; which requires giving priority in water allocation to personal and domestic uses for all, stating that:

"The human right to water entitles everyone to sufficient, safe, acceptable, physically accessible and affordable water for personal and domestic uses.", (Dubreuil, 2006).

Nevertheless, the rational application of market-based approaches may be recommended in order to accomplish water security while protecting the society's stability. These approaches include; among others; water-use charges, pollution charges and fines and the allocation of water to the more profitable activities. Water pricing has been partially applied to avoid public rejection due to the inherited social and economic rights over decades to get water for low unrealistic charges or even for free without solving the problem (Dinar \& Subramanian (eds.), 1997).

\section{Objectives of Water Pricing strategy:}

International human rights law entails specific obligations to ensure everyone's access to a sufficient amount of safe drinking water, personal sanitation, washing of clothes, food preparation, and personal and household hygiene (OHCHR, 2010). 
The application of a successful water pricing strategy helps in (Webber et al., 2008 \& The PERR Project, 2013):

- Providing incentives for efficient water use.

- Funding the management and development of water infrastructure through cost recovering.

- Equitable distribution and efficient allocation of water.

- Sustaining wastewater treatment and management.

- Readdressing land usage; as water and land use are interrelated, to reach the best land usage.

- Redistribution of income.

\section{Principles of Water Pricing Strategy:}

According to the national government priorities, the following principles should be ordered according to their importance from most importance to least importance (PERR, 2013):

- National water security.

- Equitable economic development.

- Social equity.

- Ecological sustainability.

- Financial sustainability, and Economic efficiency.

\section{Water pricing strategy as a water saving tool:}

Internationally water pricing has been used as a water saving tool; by encouraging users to use water more efficiently. As in water-abundant countries, saving water is intended to save the environment. While in water scarce countries; water pricing is intended to rationalize the use of water. 
Nonetheless, water pricing effectiveness as a water saving tool depends on the price elasticity of demand as with low elasticity an increase in prices may not impact the used amount of water (Webber et al., 2008).

The recovery of water services costs should take into consideration the costs arising from the pollution damage or negative impact on the aquatic environment implementing "the polluter pays principle" in charging water users (The European Parliament \& Council, 2000).

\section{Water pricing may reflect one or more of the following (Kebiri, 2009):}

- Cost: the operating and management costs (O\&M), capital cost, or any other economic costs.

- Value: the monetary value of the direct and indirect benefit of water to users.

- Price: is the given amount of money against using water.

\section{Components of Water Cost and Value:}

The cost of water is associated with the provision of water, while the economic value of water is derived from the use of water (Kebiri, 2009). There are different concepts of water costs based upon the incorporated components. These concepts vary from the full supply cost to the full economic cost and the full cost as shown in Figure 1. 
J. Environ. Sci.

Institute of Environmental Studies and Research - Ain Shams University

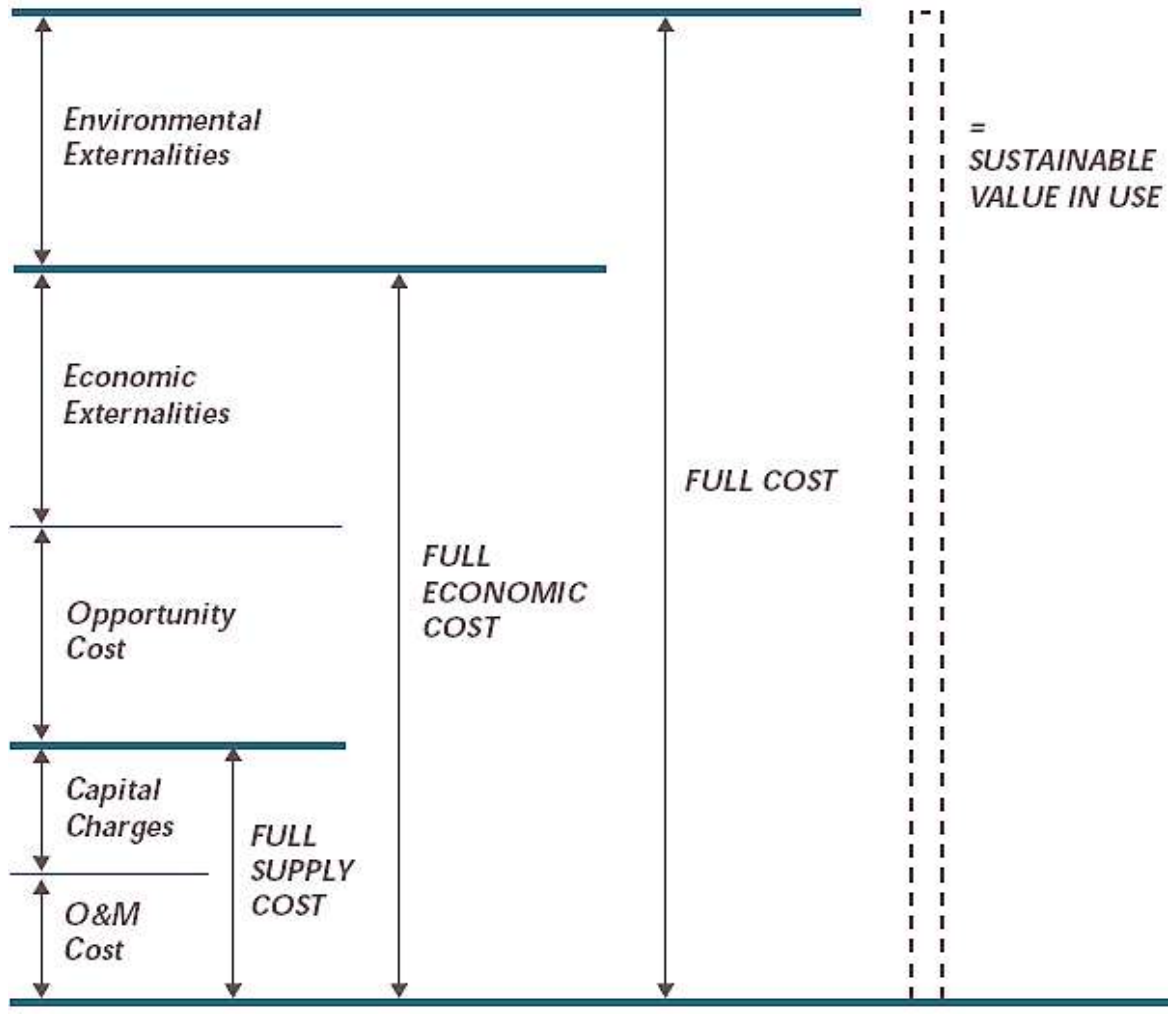

Figure 1 : Various Components of Water Costs (Rogers et al., 1998)

The full supply cost incorporates the costs associated with the supply of water from the operation and maintenance (O\&M) cost of the supply system to the capital cost including depreciation charges, interest costs, replacement costs, treatment plants, distribution network, etc.

While the full economic cost is the total of adding up the opportunity cost and the externalities to the full supply cost. Where the opportunity cost is the cost associated with the alternative use of the resource or the cost of depriving another user of water either imposed on individuals or on the 
society due to the misallocation of the resource including the cost of being deprived of clean drinking and irrigation water due to the allocation of water to other sectors; such as cost of working days lost due to illness, health care costs, wasted time in fetching water, costs associated with school dropping, costs against threatening the personal security of women and children during long distance walks to fetch water, costs associated with loss of privacy in using public toilets, the environmental quality degradation, etc. On the other hand, externalities are the costs imposed upon others due to the use of water by a specific consumer e.g. downstream users; including the costs associated with over-extraction, pollution and salinization of a common resource, in addition to the costs of internal migration due to lack of enough water in rural locations.

While the full cost of water consumption represents all the mentioned costs in addition to the environmental externalities which include the caused damage to the resource, the treatment cost of runoff to maintain the quality of the resource; which may be calculated based upon the type of effluent, load of effluent, or costs charged to treat a particular effluent (Jones, 2003).

On the other hand, water value may be determined based upon the following:

As a precious resource vital for life; water is invaluable. Economically wise; the value of water in use should equal the full cost. But due to the users' inherited social, political and economic rights over decades, the practical application allows people to get water for lower unrealistic charges or even for free, negatively affecting the society's welfare, the quality of water and the provision of water services (Kebiri, 2009). 
The economic value of water is determined according to its value to users, benefits from the indirect use of water and the return flow, as well as the adjustments for societal objectives including the adjustments made for poverty alleviations, employment and food security (Rogers et al., 1998 \& Martin-Hurtado, 2012). Where the value of water for industrial and agricultural uses is related to the marginal value of product or the additional value to the society of an additional unit of water. Where the benefits from the indirect uses of water; e.g. in rural areas irrigation canals provide water not only for irrigation but also for drinking and livestock uses. While the full value of water includes its economic value in addition to its intrinsic value (Figure 2). An example is presented in Figure 3 on estimating the value of irrigation water.

The return flows from water diverted for any particular use constitute an important part of closed hydraulic systems such as the Egyptian's one; adding additional values to water presented in recharging groundwater, providing irrigation water for canals' end tail users, etc. providing additional benefits to the society. However, these benefits may be minimized or even adverted by many factors of which hot dry climate increasing evaporation rates in opened water bodies, pollution, saline water intrusion, water logging, etc.

The benefits associated with the environmental management of water are the current user values (direct and indirect) and the intrinsic values. The intrinsic value of water can be considered; due to use of the resource as an externality or as a benefit; such as the case in gaining advantage due to; e.g. a water view or green area. In such a case the hedonic price index is used to 
determine the intrinsic value of water use that is part of the full value when added to the economic value of water.

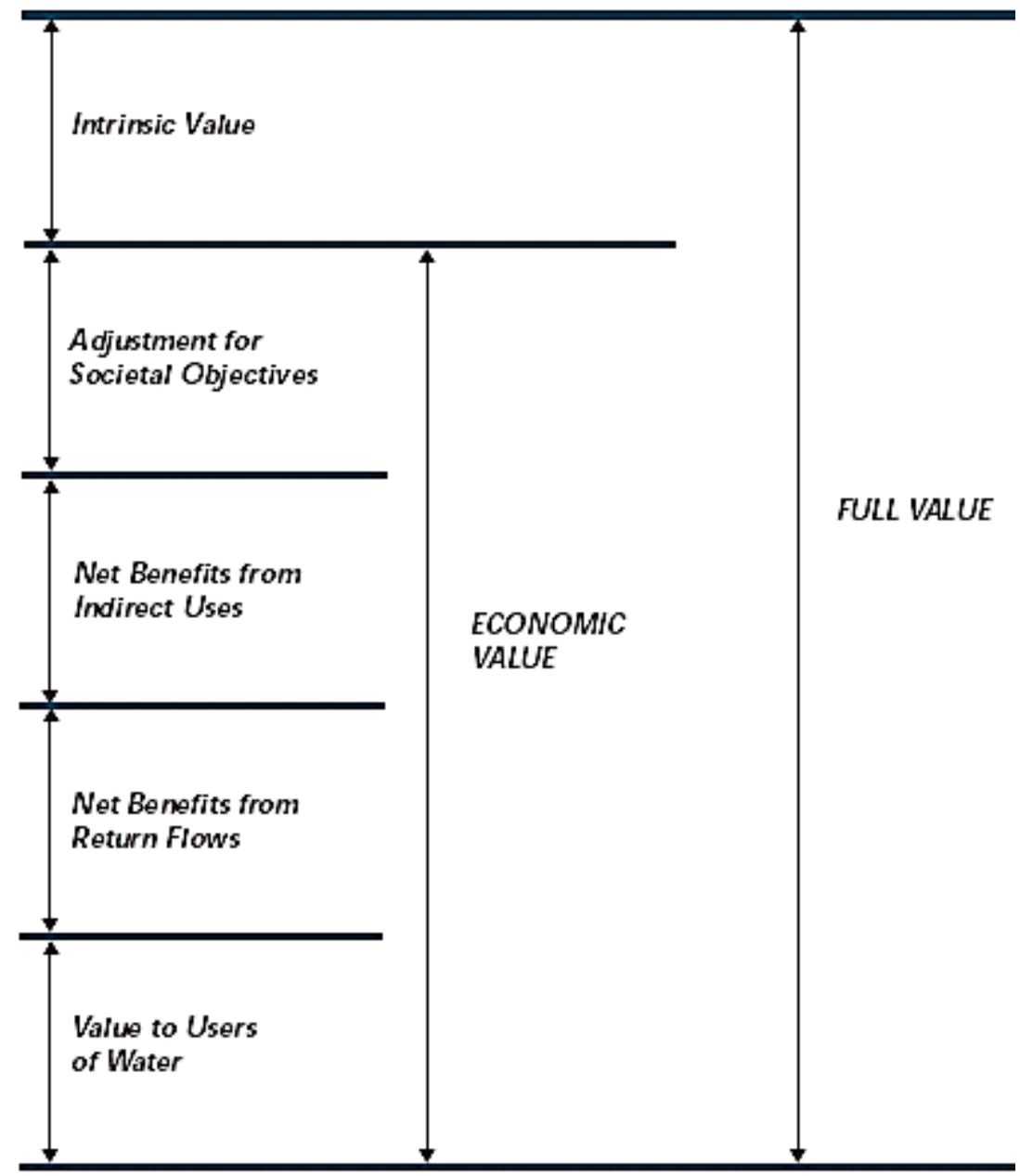

Figure 2: Water Value in Use 
J. Environ. Sci.

Institute of Environmental Studies and Research - Ain Shams University

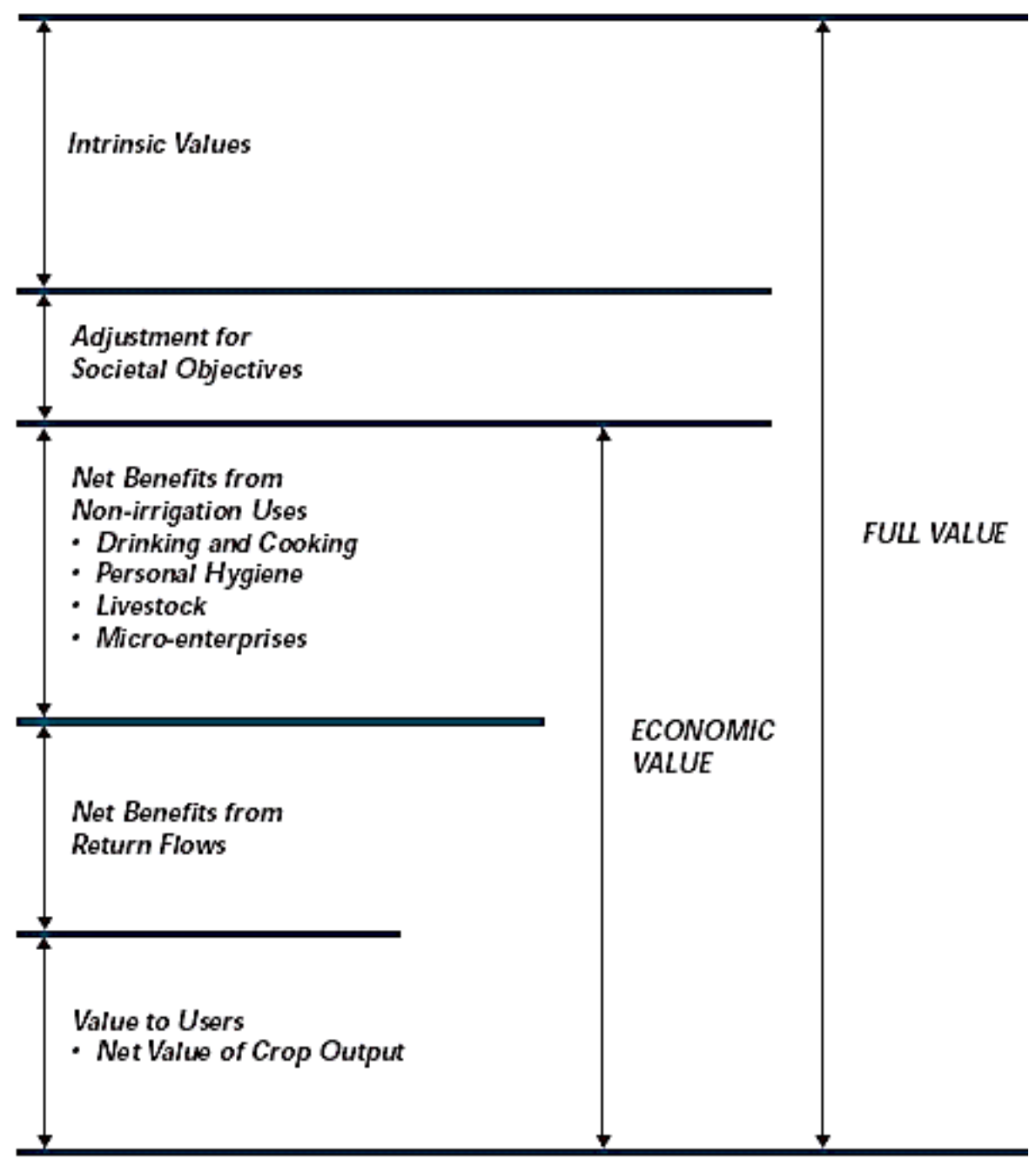

Figure 3: Irrigation Water Value Estimation

\section{Water Markets as a Water Pricing Tool:}

There are a number of pre-conditions that should be fulfilled in order to determine water prices through water markets, and missing any of the following conditions hinders pricing water through this method (Adopted from Webber et al., 2008): 
- Users should have rights to a stated volume of water per period (year, quarter, season, etc.).

- Users have the legal right to sell their water rights to others and water can be moved from sellers to buyers.

- Conflicts arising from fluctuations in river flow, pollution, return flow, etc. can be solved by a management system.

- All parties are fully informed.

- Water users act rationally on the individual and collective level.

- The use of water does not result in any externalities.

- There is complete competition.

- The paid price by users equals marginal cost of supply equals marginal productivity of water.

Of the above, we can conclude the practical difficulties in applying water markets as a water pricing tool.

Water Pricing for different users (resource fee and/or infrastructure charge) May be Based Upon (Webber et al., 2008):

Pricing irrigation water helps in recovering the cost of water delivery services, encourages the efficient use of scarce water as well as participates in sustaining investments in the sector preconditioned that it does not affect equity.

- Area: as a fixed price per feddan of irrigated land (could be combined with a quota) or a set of fixed prices per feddan according to type of land.

- Crop: to set variable prices for each crop grown or for each season or both.

- Volumetric: to set a fixed or variable price per unit of delivered water.

- Multipart: by combining one or more of the above mentioned system with 
the volumetric system.

Nonetheless, irrigation water pricing is not always the best choice when taking into consideration the fact that farmers represent the poorest group in the society and securing their livelihood helps in securing the society as a whole. Knowing that irrigation water is provided to hundreds of millions of small farmers in China with far less than its cost although they sell their products commercially clarify the significant public benefits targeted by this policy, of which:

- Low rural landlessness, as well as low and reduced poverty rates.

- Domestic food production grow faster than population and for cheap prices which reduced demand for grain allowing to keep grain production stable, avoiding price rises on the world market.

- Lowered migration rates from rural to urban locations due to securing rural livelihood.

- The empowerment of Chinese farmers to use low-priced water in producing commercial food provide a rural social security system for those working in other sectors as they can return at any time to the land and help their rural families in agriculture productive activities sustaining a livelihood for themselves and their families.

Webber et al. (2008) confirm that despite the fact that irrigation water prices might be less than cost but increasing the price of irrigation water would negatively impact the farmers' welfare.

Pricing water for domestic and industrial uses may be in the form of flat tariffs, block tariffs, subsidies, and volumetric pricing through metering the 
withdrawn quantities (Kebiri, 2009). Water pricing often comprise fixed and variable components. Fixed component varies greatly across countries according to their objectives in charging for water. While volumetric charges are almost similar across countries with varying per-meter charges due to the different use of subsidies and the application of the polluter-pays-principle (Dinar \& Subramanian (eds.), 1997). While the success of a water pricing strategy as a water-use efficiency tool, depends upon the metering of water consumption for individual user and on applying an increasing-block tariffs for each additional used-unit of water or unit of wastewater treated. Nonetheless, this is not the case for most of the users of water, e.g. municipal use is metered for water supplies entering the building not each apartment, which negatively impact the success of the implemented strategy. As each individual tries to use the biggest bulk of water against his paid share of the bill that reflects the consumed amount of water by the whole building not by his own flat (Jones, 2003).

Rogers et al. (1998) confirm that the set price of water may differ among sectors. As the case of adjusting water price in the municipal and agricultural sectors for the sack of poverty alleviation, employment, food security, etc. Although the revision of the pricing strategy is important, and should be addressed within the revision of the bigger chain (The PERR Project, 2012).

\section{Water Supplies Reliability:}

Water management and pricing policies focused on supply cost recovery and ignored the sustainability of water supplies; which increases the augmentation costs associated with suspecting the reliability of water supplies. These costs may reach 20 percent of the net value of the irrigated 
crops (Rogers et al., 1998). Impact the production levels in the industrial and thermal power plants. While in the municipal sector; women and children are the most affected due to the lost time and effort spent in fetching water that may affect school attendance as well as exposing their personal safety to risk on the long daily journeys. Not to mention the fact that the poor pay on average twelve times per liter than their counterparts with a municipal supply (WHO, 2003 \& OHCHR et al., 2010). It's worth mentioning that sustaining water supplies required the allocation of big investments in increased storage capacity, pumping, and non-traditional water supply. On the other hand, it would lead to increased evaporation levels in hot and dry seasons. Moreover, focusing on cost recovering ignores the treatment cost of wastewater, which may be extremely high in the industrial sector and defers from industry to industry. Some countries determine wastewater treatment charges according to types of pollutants found in water (Jones, 2003).

\section{Conservation-oriented water pricing strategy:}

According to Schneemann; Illinois-Indiana Sea Grant Project- water resource economist; conservation-oriented water pricing strategy varies from incorporating the full cost of water to send correct signals to water users and encourage them to more efficient resource use, to seasonal pricing strategyincreasing water rates during the summer when water use is at its peak eliminating pressure on water systems, improving water billing, etc. Nonetheless, and regardless of the effectiveness of conservation programs to be adopted; without informing the people about the preciousness of water, the need to conserve it and the details on the billing system, these programs will 
not reach their goals (Adopted from Peterson Jason, 2010).

Water pricing enters into action either via governmental forces or by market forces. Nonetheless, it is not advisable to use it as a stand-alone tool to save water. In order to save the environment and the societal socio-economic stability, there are a number of measures that may enhance water use efficiency either by its own or combined with water pricing (Webber et al., 2008 \& Dono et al., 2010). of these measures:

- Informing farmers with the negative marginal returns that may be caused by over applying water to the land and that more water than optimal reduces yields. As well as to inform then with the best type of crops that maximize their return while saving water (farmers' awareness campaigns).

- The withdrawal of water may be rationalized by canal dimension and pump capacity.

- The paid cost for pumps and for diesel to left water to the field determine together with the paid fees for water and infrastructure fees the actual elasticity of demand for water which is calculated according to Webber et al. (2008) as follows: $\mathrm{e}^{-} \mathrm{e}^{\prime}(\mathrm{p}+\mathrm{p} 1) / \mathrm{p}$ where $\mathrm{e}^{\prime}$ is the estimated elasticity, $\mathrm{p} 1$ is the pumping and other costs the farmers pay and $p$ is the direct price of water. it is worth mentioning that the more the farmer lefts water the more he pays for pumping water and that this cost may reach up to 30 times the paid price for water in a country like China that leads us to the conclusion that although water is not metered but the farmer in this case pays a volumetric price for getting water to his field. Thus, the core of water efficiency problem is not the absent of a metering system for irrigation water rather than it is in the system itself that does not encourage farmers 
to conserve water.

\section{Water Price Elasticity:}

Elasticity demonstrates expected changes in demand in response to changes in prices. According to a number of studies, water price elasticity in the residential sector water on average -0.51 (Espey et al., 1997 cited in Olmstead, 2010) and that the residential price elasticity may increase when price information is posted on water bills (Gaudin, 2006 cited in Olmstead, 2010). While elasticity be higher under increasing-block prices when the marginal water price increases with consumption than under uniform volumetric (Olmstead et al., 2007 cited in Olmstead, 2010).

\section{The Driving-Forces towards Failure of Water Pricing Systems:}

- The inherited believe that water is abundant and that it is available at any time pricelessly.

- The system does not offer incentives for water conservation, nor imposes penalties over water wasting or miss-use.

- Pricing irrigation water will impose additional burden over the famers who represent the poorest members of the society.

- The lack of a solid-wastes' recycling strategy led to the disposal of these solids into water ways polluting water and stimulating the cost of water delivery and treatment.

- The absence of clear regulations to charge industrial point-source polluters against their damage to the environment.

- Water metering is not connected with each flat but rather and in most cases connected with the total consumption of the whole building; which leads 
to uncontrolled usage of water as each department tries to use water more than any of its neighbors.

\section{REFERENCES}

Dono G., Giraldo L., and Severini S., 2010, "Pricing of Irrigation Water under Alternative Charging Methods: Possible Shortcomings of a Volumetric Approach", Agricultural Water Management Journal, Elsevier, Volume 97 (11), November, pages 1795-1805.

Doss Mervat and Milne Grant, 2001, "Water as an Economic Good: An Approach to the Egyptian Economy", the Beijer Workshop on "Property Rights Structures and Environmental Resource Management" Egypt.

Dubreuil Céline, 2006, "The Right to Water: from concept to implementation", ISBN: 92-95017-11-0, the World Water Council, France.

Jones T., 2003, "Pricing Water", OECD Observer no. 236, March 2003, The Organization for Economic Cooperation and Development, Available from: http://www.oecdobserver.org/news/fullstory.php/aid/939/Pricing_ water.html, Accessed on 6.5.2016.

Kebiri A., 2009, "Water Pricing, a Viable Solution for Egypt's Water Crisis?", World Environment Magazine no. 3, June 2009, pp. 7074, Accessed From: https://issuu.com/worldenvironment/docs/we_3, Accessed on 14.8.2016.

Martin-Hurtado R., 2012, "Pricing water resources to finance their sustainable management- A think-piece for the EUWI Finance Working Group", May 2012, the European Union Water Initiative Finance Working Group (EUWI-FWG) and Global Water Partnership, Stockholm, Sweden.

OHCHR (Office of the High Commissioner for Human Right), UN (United Nations), UN-HABITAT (United Nations Human Settlement Programme) and WHO (World Health Organization), 2010, "The Right to Water", Fact Sheet No. 35, Geneva, Switzerland. 
Olmstead Sheila M., 2010, "The Economics of Managing Scarce Water Resources", Review of Environmental Economics and Policy, volume 4, issue 2, summer 2010, pp. 179-198, Oxford University Press on behalf of the Association of Environmental and Resource Economists.

PERR (Pricing and Economic Regulator Review) Project, 2012, "Raw Water Pricing Strategy Gap Analysis", Project to Revise the Pricing Strategy for Water Use Charges and Develop a Funding Model for Water Infrastructure Development and Use and a Model for the Establishment of an Economic Regulator, 30 October 2012 WP10465, the Dept. of Water Affairs, Republic of South Africa, Available http://www.dwaf.gov.za/Projects/PERR/documents\%5CPricing\% 20Strategy\%20Gap\%20Analysis\%20\%206\%20November\%202012.pdf, Accessed Oct. 8, 2013.

PERR (Pricing and Economic Regulator Review) Project, 2013, "Raw Water Pricing Strategy Gap Analysis", Project to Revise the Pricing Strategy for Water Use Charges and Develop a Funding Model for Water Infrastructure Development and Use and a Model for the Establishment of an Economic Regulator, 30 February 2013 WP10465, Available at www.dwa.gov.za/Projects/PERR/documents/Pricing\%20Strategy \%20Gap\%20Analysis\%20-\%206\%20November\%202012.pdf,

Accessed Oct. 8, 2013, the Dept. of Water Affairs, Republic of South Africa.

Peterson J., 2010, "Strategies for water conservation: Is the price right?", (The HELM) of Illinois-Indiana Sea Grant, Miles Irene (Ed.), Winter $2010 \quad$ Newsletter, Accessed through www.iisgcp.org/newsroom/helm/helm10_winter_web.pdf, Accessed on Oct. 9, 2013.

Rogers P., Bhatia R., and Huber A., 1998, "Water as a Social and Economic Good: How to Put the Principle into Practice", Global Water Partnership Technical Advisory Committee (TAC), BACKGROUND PAPERS NO. 2, ISSN: 1403-5324, Stockholm, Sweden. 
UN (United Nations), OHCHR (Office of the High Commissioner for Human Right), UN-HABITAT (The United Nations Human Settlements Programme) and WHO, 2010, "The Right to Water", Fact Sheet No. 35, United Nations, Geneva, ISSN 1014-5567.

UNDP (United Nations Development Programme), 2006, "Human Development Report 2006: Beyond Scarcity: Power, Poverty and the Global Water Crisis", (Eds.) Bruce Ross-Larson, Meta de Coquereaumont and Christopher Trott, United Nations Development Programme, Palgrave Macmillan, New York, ISBN 0-230-50058-7, Available from: http://www.loc.gov/catdir/enhancements/fy0801/2007382796t.html, Accessed 20/10/2011.

Webber M., Barnett J., Finlayson B., and Wang M., 2008, "Pricing China's irrigation water", Global Environmental Change 18 (2008), Elsevier Ltd., pp. 617-625.

World Bank, 2016, "High and Dry: Climate Change, Water, and the Economy", the International Bank for Reconstruction and Development- The World Bank, Washington, DC, License: Creative Commons Attribution CC BY 3.0 IGO.

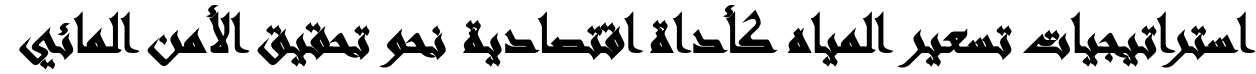

\section{[द]}

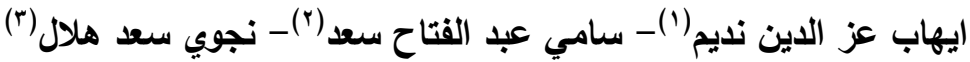

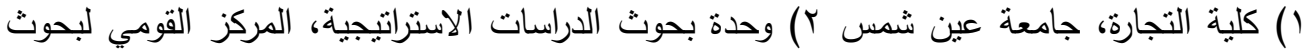

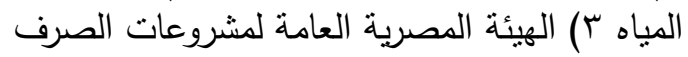

$$
\begin{aligned}
& \text { المستصنص: }
\end{aligned}
$$

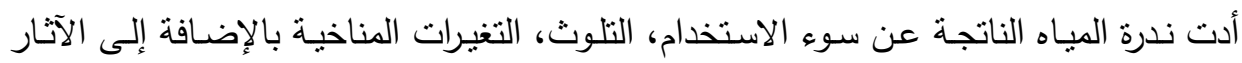

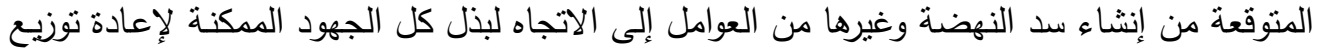

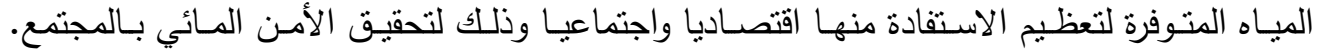

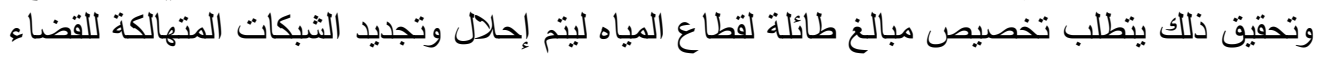

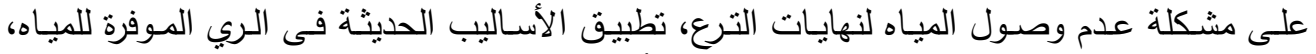

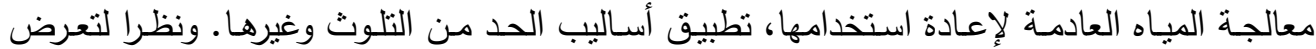

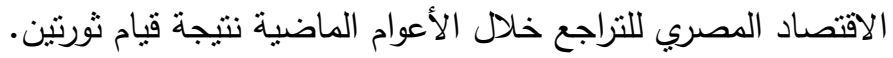




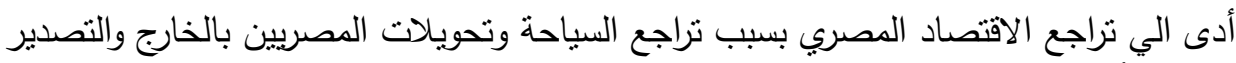

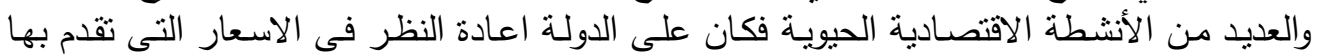

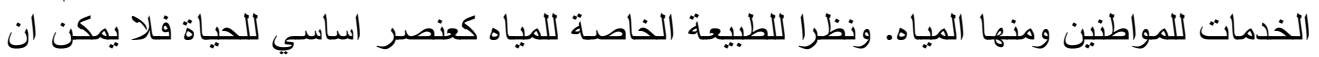

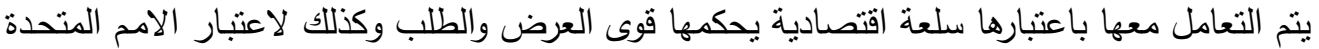

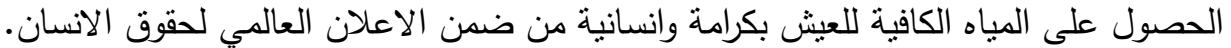

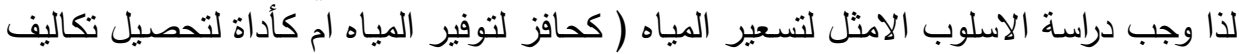

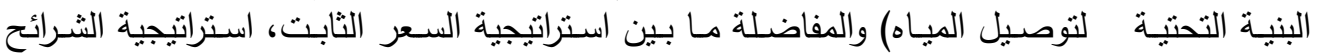

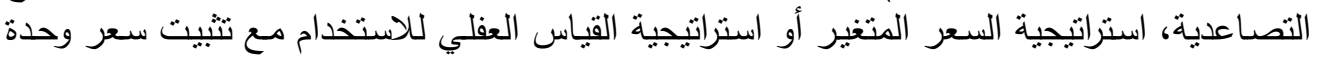

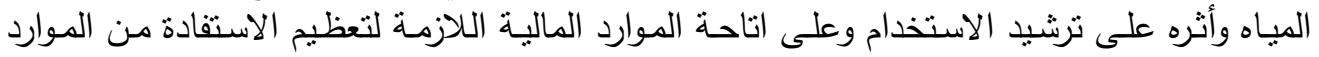

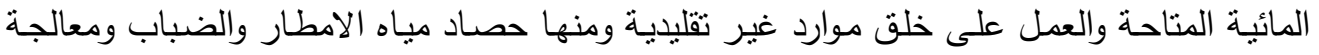
مياه الصرف وتحلية مياه البحر واستخراج المياه الجوفية. وذلك باستخدام اسلوب التحليل الوصفى بالتطبيق على المعلومات التحات والتقارير المنشورة على شكة

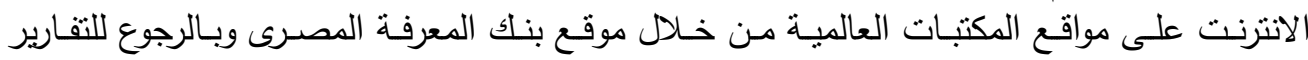

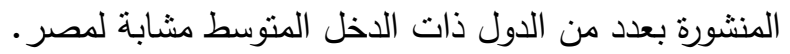

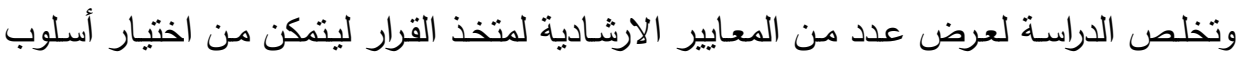

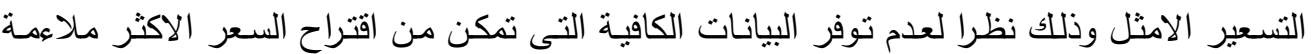

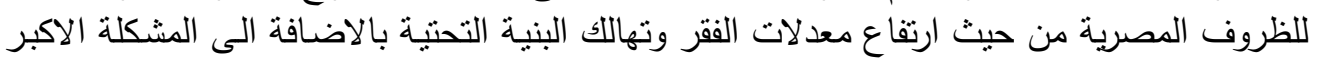

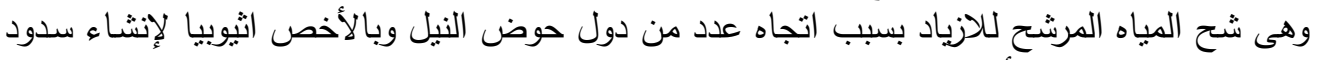

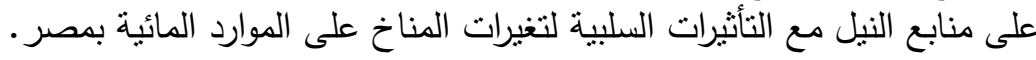

